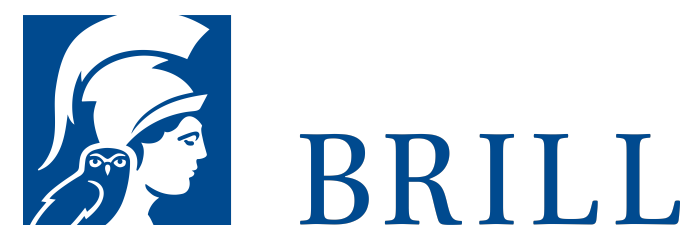

\title{
Ostraka Varia
}

Tax Receipts and Legal Documents on Demotic, Greek, and Greek-Demotic Ostraka, Chiefly of the Early Ptolemaic Period, from Various Collections (P. L. Bat. 26)

Author: Vleeming

A large majority of the 65 ostraka published in this volume come from Egypt in the Third Century B.C. Some thirty are from Elephantine; these comprise a number of Greek and Greekdemotic receipts. Not unimportant new texts from Hermonthis and Thebes (among others, a fine example of a temple oath) add notably to the diversity of the volume. Although of course tax receipts predominate, these are present in a rich variety, and their commentaries add much to our knowledge of fiscal matters in this period.

As a nouveaut $\tilde{A} \odot$ the Greek and demotic texts are published on exactly the same footing, and a constant effort is made to merge the separate worlds of Greek and demotic papyrology. Hand-facsimiles facilitate the consultation of the individual texts; the whole is rounded off by photographic plates showing all texts in full.

\section{Readership}

All those from the fields of Classical History, Legal History, Egyptology, Papyrology, interested in Egypt in the Late Period, as well as those interested in Egyptian (notably demotic) philology.

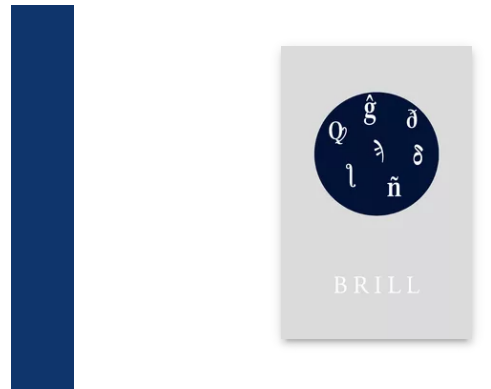

Pages: xiii, 173 pp. num. figures, $16 \mathrm{pl}$.

Language:

English

Subjects:

General,

Classical

Studies,

Codicology,

Papyrology \&

Philology,

Ancient Near

East and Egypt

Publisher: Brill

Series:

Papyrologica

Lugduno-

Batava, Volume:

26

E-Book (PDF)

Released online:

og Mar 2020

ISBN: 978-90-

04-4278o-8

List price

USD. Â $\$ 202.00$

Hardback

Publication date:

o1 Nov 1994

ISBN: 978-90-

o4-10132-6

List price 
S.P. Vleeming, reader in demotic Papyrology in the University of Leiden, specialises in the study of the juridical documents of Late Period Egypt.

For more information see brill.com

Order information: Order online at brill.com +44 330 333 0049 | customerservices@brill.com Submission information: brill.com/authors

Titles published by Brill | Fink, Brill | mentis or Brill | Schöningh: +49(o)71 5413279216 | brill@brocom.de 